VanGrasstek, C. (2011), "Employment and the Political Economy of Trade: A Structured Review of the Literature", OECD Trade Policy Working Papers, No. 133, OECD Publishing.

http://dx.doi.org/10.1787/5kg3nh4jlv0x-en

\title{
OECD Trade Policy Working Papers
} No. 133

\section{Employment and the Political Economy of Trade}

\author{
A STRUCTURED REVIEW OF THE LITERATURE
}

Craig VanGrasstek

A product of the International Collaborative Initiative on Trade and Employment (ICITE) 


\title{
OECD TRADE POLICY WORKING PAPERS
}

The OECD Trade Policy Working Paper series is designed to make available to a wide readership selected studies by OECD staff or by outside consultants.

This paper has been developed as a contribution to the International Collaborative Initiative on Trade and Employment (ICITE) coordinated by the OECD. The views expressed are those of the author and do not necessarily reflect those of the OECD, OECD member country governments or partners of the ICITE initiative.

This document and any map included herein are without prejudice to the status of or sovereignty over any territory, to the delimitation of international frontiers and boundaries and to the name of any territory, city or area.

This document has been declassified on the responsibility of the Working Party of the Trade Committee under the OECD reference number TAD/TC/WP(2011)19/FINAL.

Comments on the series are welcome and should be sent to tad.contact@ oecd.org.

\author{
OECD TRADE POLICY WORKING PAPERS \\ are published on www.oecd.org/trade
}




\title{
Abstract \\ EMPLOYMENT AND THE POLITICAL ECONOMY OF TRADE: A STRUCTURED REVIEW OF THE LITERATURE
}

\author{
Craig VanGrasstek ${ }^{1}$ \\ Harvard University and Consultant to the OECD
}

\begin{abstract}
The aims of this paper are to review the main schools of thought on the political economy of trade and employment, to review the empirical evidence supporting these schools, and to consider the implications for public policy. Special emphasis is given to the potential costs of liberalization and the manner that concerns about these costs may inhibit countries' willingness to open markets and thereby limit the potential gains from trade. These issues are explored through a structured examination of the political economy literature, including the contributions of political scientists, economists, and historians, focusing on the role of different types of political actors in the formation of policy concerning trade-and-employment issues. Those actors include the general public (the members of which are simultaneously workers, consumers, and voters); economic interests (firms, associations, and labour unions); and policy makers in both the executive and legislative branches of government. The paper proceeds in three steps, the first being to define each of the main schools of thought. The next step is to review empirical studies that have tested the validity of these schools of thought. The third and final step is to consider complementary policies.
\end{abstract}

JEL classification: F16 (Trade and labour market interactions).

Keywords: Trade, employment, wages, inclusive growth.

1. Craig VanGrasstek at TradeProf@aol.com . The author wishes to thank Marc Bacchetta (World Trade Organization), Douglas Lippoldt (Organization for Economic Cooperation and Development), and Robert Z. Lawrence (Harvard Kennedy School) for helpful comments on an earlier draft. Any errors that remain are his own 


\section{Acknowledgements}

The OECD-led International Collaborative Initiative on Trade and Employment (ICITE) has brought together ten international organisations in an effort to deepen our understanding of the linkages between trade and jobs and to develop policy-relevant conclusions. ICITE is mobilising resources world-wide in an extensive programme of research, dialogue and communications. Participating organisations include: ADB, AfDB, ECLAC, IADB, ILO, OAS, OECD, UNCTAD, World Bank and WTO. The OECD is publishing this series of Trade Policy Working Papers drawing on the ICITE research programme.

The ICITE project is being implemented under the auspices of a team at OECD. Douglas Lippoldt is the project manager and Secretary to ICITE. In relation to the ICITE working papers, Ania Jankowska and Monika Sztajerowska provided analytical, editorial and other substantive inputs, and Katjusha Boffa and Jacqueline Maher provided secretarial and administrative support. The OECD ICITE team is based in the Development Division, headed by Michael Plummer, and under the direction of Raed Safadi, OECD Deputy Director for Trade and Agriculture, and Ken Ash, OECD Director for Trade and Agriculture.

The OECD ICITE team gratefully acknowledges the quality of the submissions received from the working paper authors. The papers have benefitted from comments and other support from ICITE partner organisations (especially members of the ICITE Steering Committee), the Working Party of the OECD Trade Committee and other national experts, participants at the three ICITE regional conferences held during 2011 in Africa, Asia and Latin America, and other parts of the OECD (especially the Directorate for Employment, Labour and Social Affairs). Their contributions helped the authors and the OECD to further develop these papers and other aspects of the ICITE project.

This paper has been developed as an input to the ICITE project. The views expressed are those of the author(s) and do not necessarily reflect those of the OECD, OECD member country governments or partners of the ICITE initiative. 


\section{Table of contents}

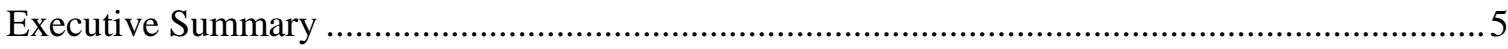

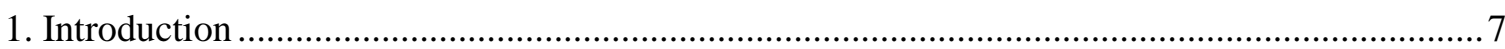

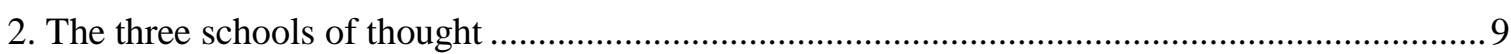

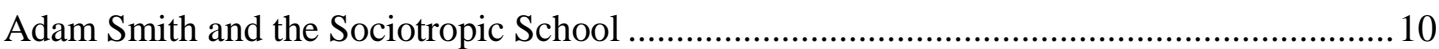

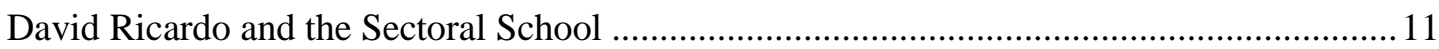

Stolper-Samuelson and the Factor-Endowments School ...................................................... 12

3. Empirical studies of how political actors approach trade policy ................................................ 14

The Demand Side I: The concerns of worker/consumer/voters ............................................. 14

The Demand Side II: The conflict between interest groups ..................................................... 16

The Demand Side III: The objectives of labour unions ......................................................... 17

The Supply Side: How policy makers sort out these demands .............................................19

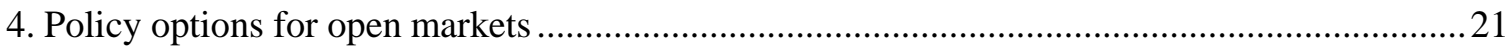

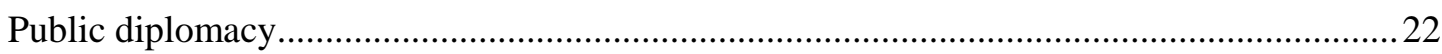

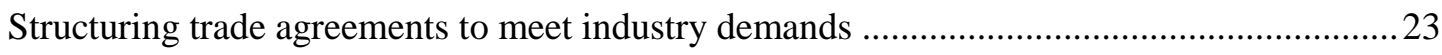

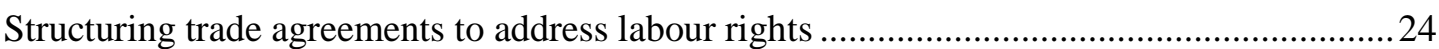

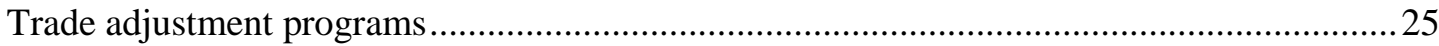

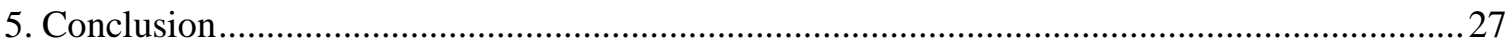

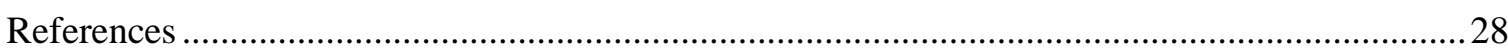




\section{Executive Summary}

This paper reviews the main schools of thought on the political economy of trade and employment. These issues are explored through a structured examination of the political economy literature, including the contributions of political scientists, economists, and historians, focusing on the role of different types of political actors in the formation of policy concerning trade-and-employment issues. Those actors include the general public (the members of which are simultaneously workers, consumers, and voters); economic interests (firms, associations, and labour unions); and policy makers in both the executive and legislative branches of government.

The paper proceeds in three steps, the first being to define each of the main schools of thought. These perspectives differ according to how they portray individuals' conceptions of their interests, which might variously be defined at the level of community (per Smith), the industries in which they are employed (per Ricardo), or according to their skills and other factor endowments (per Stolper-Samuelson). The answer to that foundational question of interests affects how policy makers receive and respond to the associated demands. A Smithian or sociotropic view stresses the concerns over the impact that liberalization may have on the most vulnerable members of society, and could inhibit market-opening measures; in a Ricardian or sectoral system, the decision of whether or not to open markets will depend on the relative political strength of the industries that favour or oppose this move; and in a Stolper-Samuelson or factor-based approach, we should expect liberalization to be more popular among those whose skill sets and other endowments are most likely to thrive in an open market, and to be opposed by those who fear being left behind. The distinctions between the latter two approaches are sometimes subtle, but both of them differ markedly from the first.

The next step in the paper is to review empirical studies that have tested the validity of these schools of thought. The conclusions that an analyst reaches will often depend on which kind of actor they choose as the focal point of their research: Studies that focus on individuals are the most likely to find evidence supporting the Smithian position (though many of them deviate from this pattern); those that examine the positions of firms, industries, and interest groups tend to assume a Ricardian perspective from the start; and analyses of labour unions are frequently founded upon a Stolper-Samuelson viewpoint. It is policy makers who must ultimately reconcile the various demands made upon them, decide whether and how to open markets, and also consider other policy options that might complement trade liberalization.

The third and final step in the paper is to consider those complementary policies. Some of these options very roughly correspond to the three different perspectives, based as they are on different assumptions regarding the nature of the problem and the appropriate solution. Among the options are a "public diplomacy" campaign that stresses the benefits of liberalization (thus appealing to Smithian sentiments); structuring trade agreements to meet the demands of industry or to allow for contingent protection (a Ricardian approach); or to bring labour rights into trade agreements (a Stolper-Samuelson 
response). The one option that seems to speak to each of the three perspectives is to provide trade adjustment programs to aid displaced workers, an approach that has appeal for Smithians (insofar as the assistance addresses the needs of the most vulnerable), Ricardians (as it can be directed to specific industries), and those with Stolper-Samuelson concerns (as it can help give workers the skills they need to succeed in a new, more competitive environment). This is not to say that trade adjustment programs are without controversy, however, as there are critics who attack them on grounds of both principle and practice.

An important caveat in the approach applied in this paper is that it is an examination of the political economy of trade and employment and not of trade economics per se. While reference is made to some empirical studies that deal with the actual consequences of trade, no attempt is made here to pass judgement on the theoretical or empirical validity of (for example) the Stolper-Samuelson theorem or any other models regarding the magnitude and distribution of trade's costs and benefits. The emphasis here is on how voters, interest groups, and policy makers perceive the consequences of trade, how they define their interests, and how they act politically when dealing with these economic phenomena.

The principal theme that runs through this review is that while the distinctions between the main schools of thought are clear in principle, in actual practice it is difficult to determine which may most accurately capture reality. Depending on the ways that researchers elect to frame their questions, the data they choose to examine, and the methods they employ, one can find support for each of the main schools of thought. The resulting ambiguity leaves both researchers and policy makers considerable latitude in how they interpret the information and act upon it, and complicate the effort to devise a set of "best practices" for managing the process of negotiating, approving, implementing, and adjusting to market-opening agreements. Thus, there is no simple conclusion with an axiomatic rule as to how policy makers should execute their responsibilities.

The empirical analyses reviewed here reveal a great diversity in methods, data, and conclusions. At one extreme are those studies that concentrate only on the principals and that, by implication, leave no room for independent thought or action by the statesmen or lawmakers who act as their agents. Whether those principals think and act solely on the basis of self-interest remains a matter of dispute. At the other extreme is the evidence that, in some countries and for some initiatives, trade policy is a reflection of the agents' ideological attachments or an elective instrument of their foreign policy. The observed variation in the characteristics and practices of countries lead us to a conclusion that is safe, inevitable, but not very satisfying: It depends. If one is allowed to choose cases or other evidence freely, one can find data to support or undermine any of the proposed policymaking relationships.

The complexity of relationships between the general public, the private sector, and policy makers should not distract us from the larger point: Concerns over the impact of trade liberalization on employment can affect countries' willingness to engage in that liberalization. That remains true whether these concerns are based on individuals' selfinterest or their concern for others; whether they are worried about what free trade might mean for the industry that employs them or the skill categories into which they fall; whether it is firms or unions that are calling the shots; and whether policy makers merely act on the demands they receive from their principals or they take other ideas and interests into consideration. 
"The ideas of economists and political philosophers, both when they are right and when they are wrong, are more powerful than is commonly understood. Indeed the world is ruled by little else. Practical men, who believe themselves to be quite exempt from any intellectual influence, are usually the slaves of some defunct economist."

John Maynard Keynes, The General Theory of Employment Interest and Money (1936: 383)

\section{Introduction ${ }^{2}$}

Debates over the political economy of trade and employment offer an illustration of Keynes' claims for the influence of economic ideas on public policy. Although they may not be consciously aware of it, private citizens and public officials tend to act as if directed by one of three schools of economic thought on the subject. Those three schools, which can respectively be traced back to Adam Smith, David Ricardo, and Wolfgang Stolper-Paul Samuelson, not only provide different ways of conceiving the economic consequences of trade for employment but also imply distinct means through which the concerns of people and policy makers may be addressed.

This paper reviews the main schools of thought on the political economy of trade and employment. These issues are explored through a structured examination of the political economy literature, including the contributions of political scientists, economists, and historians, focusing on the role of different types of political actors in the formation of policy concerning trade-and-employment issues. Those actors include the general public (the members of which are simultaneously workers, consumers, and voters); economic interests (firms, associations, and labour unions); and policy makers in both the executive and legislative branches of government.

The principal theme that runs through this review is that while the distinctions between the main schools of thought are clear in principle, in actual practice it is difficult to determine which may most accurately capture reality. Depending on the ways that researchers elect to frame their questions, the data they choose to examine, and the methods they employ, one can find support for each of the main schools of thought. The resulting ambiguity leaves both researchers and policy makers considerable latitude in how they interpret the information and act upon it, and complicate the effort to devise a set of "best practices" for managing the process of negotiating, approving, implementing, and adjusting to market-opening agreements.

The paper proceeds in three steps, the first being to define each of the main schools of thought. These perspectives differ according to how they portray individuals' conceptions of their interests, which might variously be defined at the level of community (per Smith), the industries in which they are employed (per Ricardo), or according to their skills and other factor endowments (per Stolper-Samuelson). The answer to that foundational question affects how policy makers receive and respond to these demands. A Smithian or sociotropic view stresses the concerns over the impact that liberalization may have on the most vulnerable members of society, and could inhibit market-opening measures; in a Ricardian or sectoral system, the decision of whether or not to open markets will depend

2. The author wishes to thank Marc Bacchetta (World Trade Organization), Douglas Lippoldt (Organization for Economic Cooperation and Development), and Robert Z. Lawrence (Harvard Kennedy School) for helpful comments on an earlier draft. Any errors that remain are his own. 
on the relative political strength of the industries that favour or oppose this move; and in a Stolper-Samuelson or factor-based approach, we should expect liberalization to be more popular among those whose skill sets and other endowments are most likely to thrive in an open market, and to be opposed by those who fear being left behind. The distinctions between the latter two approaches are sometimes subtle, but both of them differ markedly from the first.

The next step is to review empirical studies that have tested the validity of these schools of thought. The conclusions that an analyst reaches will often depend on which kind of actor they choose as the focal point of their research: Studies that focus on individuals are the most likely to find evidence supporting the Smithian position (though many of them deviate from this pattern); those that examine the positions of firms, industries, and interest groups tend to assume a Ricardian perspective from the start; and analyses of labour unions are frequently founded upon a Stolper-Samuelson viewpoint. It is policy makers who must ultimately reconcile the various demands made upon them, decide whether and how to open markets, and also consider other policy options that might complement trade liberalization.

The third and final step is to consider those complementary policies. Some of these options very roughly correspond to the three different perspectives, based as they are on different assumptions regarding the nature of the problem and the appropriate solution. Among the options are a "public diplomacy" campaign that stresses the benefits of liberalization (thus appealing to Smithian sentiments); structuring trade agreements to meet the demands of industry or to allow for contingent protection (a Ricardian approach); or to bring labour rights into trade agreements (a Stolper-Samuelson response). The one option that seems to speak to each of the three perspectives is to provide trade adjustment programs to aid displaced workers, an approach that has appeal for Smithians (insofar as the assistance addresses the needs of the most vulnerable), Ricardians (as it can be directed to specific industries), and those with Stolper-Samuelson concerns (as it can help give workers the skills they need to succeed in a new, more competitive environment). This is not to say that trade adjustment programs are without controversy, however, as there are critics who attack them on grounds of both principle and practice.

A few caveats need to be stated before beginning this review. One is that this is an examination of the political economy of trade and employment and not of trade economics per se. While reference is made to some empirical studies that deal with the actual consequences of trade, no attempt is made here to pass judgement on the theoretical or empirical validity of (for example) the Stolper-Samuelson theorem or any other models regarding the magnitude and distribution of trade's costs and benefits. Without challenging the proposition that the net results of trade liberalization will usually be positive - apart from taking note of what one author called the "[g]rowing reluctance among economists to assert inevitable net benefits of trade integration" (Giordano, 2009a: 16) - we may acknowledge that there are costs as well as benefits from liberalization, and concentrate on how political actors deal with these costs. The emphasis here is on how voters, interest groups, and policy makers perceive the consequences of trade, how they define their interests, and how they act politically when dealing with these economic phenomena. To state the matter in Keynes' terms, it is more important for our present purposes to establish whether practical men behave as if they were indeed the slaves of economists and their ideas, and to leave it to others to determine which of those economists are the most defunct. 
It is equally important to recognize that a comparative analysis of this sort is complicated by the fact that political institutions, rules, and cultures vary greatly across countries, and that the observations made in one will not always be equally valid for others. The views of voters will matter more in democracies than in dictatorships, for example, and while democracy is now the global norm there remain some countries where it is yet to be adopted and many others where it is still very much a work in progress. Even in those countries with long and vibrant democratic traditions, there are many important ways in which their formal and informal rules differ. Observations drawn from the activities of labour unions in Europe, for example, may not be readily applied to the experience of their counterparts in the United States, just as studies that focus on the role of the US Congress in trade policymaking may have limited direct relevance for the European experience. As is always the case for comparative political studies, it is therefore necessary to consider the extent to which the institutions and traditions in any given country may be unusual and in some instances may be unique. While the author has sought relevant studies dealing with countries in distinct regions and at different levels of economic development, it is an inescapable fact that the literature in this field, or at least that portion of the literature that is available in English, tends to be dominated by studies of the United States (followed in magnitude by studies of Great Britain). If the proponents of "American exceptionalism" are right, from de Tocqueville (1835) to Lipset (1996) and beyond, we need to exercise caution in deriving global lessons from many of the studies examined here.

A final caveat is that the three schools of political economy reviewed below do not exhaust the range of perspectives that might be examined. One additional approach that might be examined is the original Heckscher-Ohlin model, which may be distinguished from its Stolper-Samuelson corollary. That could be done in order to differentiate between a relatively optimistic and a relatively pessimistic perspective on how individuals might adopt a factor-based (as opposed to sectoral) conception of their interests. Given the very large overlap between Heckscher-Ohlin and Stolper-Samuelson, however, Occam's razor slices out the former and concentrates our attention on the latter. Similar reasoning is behind the decision to leave out a Marxist perspective, as that might be little more than a radicalized version of Stolper-Samuelson. ${ }^{3}$ The review that follows is thus constructed pragmatically, concentrating on the three schools that best exemplify the range of views that are most prominent in the literature.

\section{The three schools of thought}

We may start with a few simple propositions: that individuals make demands of government according to their interests, that these interests are largely (but perhaps not exclusively) conceived in economic terms, and that in any political system the policies that governments adopt will generally reflect these demands. As straightforward as that sounds, we need to know just how narrowly or broadly those individuals' interests are conceived in the first place. Do they think of themselves primarily as citizens in a broader policy whose collective interests should outweigh the narrow interests of specific groups,

3. In a Marxist construct we would expect workers to have a broad and possibly international sense of class solidarity, in line with Marx's view that "the free trade system hastens the social revolution" and "[i]n this revolutionary sense alone" he was "in favour of Free Trade" (1848: 88). The tactic of deliberately immiserating the masses is not likely to find much support in the general public of a modern, democratic society. 
as workers whose interests are tied to a specific industry, or as autonomous economic actors whose skills and resources in one sector may be more or less adaptable to uses other than the industry or firm in which they are currently employed? Depending on which of these thumbnail descriptions conform most closely to the shapes of their mental maps, people might behave as expected, respectively, by Smith, Ricardo, or StolperSamuelson. Each of these schools of thought implies a different set of ideas regarding the political economy of trade and employment with respect to how political actors (voters, interest groups, politicians, etc.) perceive the issue, how they act upon it, and what approaches might be taken to encourage liberalization and discourage protectionism.

\section{Adam Smith and the Sociotropic School}

We may start with Adam Smith and the sociotropic conception of interests. The idea dates back centuries, though the latest terminology (as coined by Kinder and Kiewiet, 1979) is new. Sociotropism is centered on notions of fairness that transcend self-interest, such that a citizen who shares this orientation is motivated by concerns over the welfare of others.

In addition to being the father of modern economics, Smith was also the author of The Theory of Moral Sentiments, ${ }^{4}$ a work in which he anticipated some core ideas of behavioural economics. The view of human nature that Smith propounded in that earlier work differs markedly from the essentially Ricardian (i.e. narrow and sectoral) concept of economic interests that he would later voice in The Wealth of Nations, placing a great deal of emphasis on the individual's regard for the wellbeing of others. Reconciling the differences between these two classics has long been a preoccupation for Smith's admirers. ${ }^{5}$ Our main interest here is on how the views in Smith's first book might affect achievement of the goals that he set out in his second.

What is at issue here are altruism and fairness, two concepts that do not figure prominently in most economic literature. They run counter to what Baumol called economists' "determined disregard for [their recommendations'] implications for distributive equity," which he suspected was a reflection of their "inability to get any analytic handle upon issues of justice in economic decisions" (1986: 1-2). Some modern economists have nonetheless attempted to devise theories of altruism and fairness based on utility, either as part of a series of iterated exchanges (e.g. Axelrod, 1984) or in which the actor incorporates the interests of others in his own utility function (e.g. Becker, 1976). Smith got the jump on them in the first line of The Theory of Moral Sentiments: "How selfish soever man may be supposed, there are evidently some principles in his nature, which interest him in the fortunes of others, and render their happiness necessary to him, though he derives nothing from it, except the pleasure of seeing it" (1790: 1).

How does this relate to trade liberalization? "One of the few uncontroversial insights of trade theory," as Goldberg and Pavcnic (2007: 7) succinctly stated, "is that changes in a country's exposure to international trade affect the distribution of resources within the country and can generate substantial distributional conflict." The welfare effects of liberalization tend to favour those producers who are already competitive, and also enhances consumer welfare through lower prices and wider choices, while placing the burden of adjustment on those sectors, firms, and workers that are less competitive. For

4. The first edition of The Theory of Moral Sentiments came out in 1759, seventeen years before The Wealth of Nations. The quotation above is from the sixth (1790) edition.

5. See, for example, Viner (1927), Coase (1976), and Herbener (1987). 
individuals with a sociotropic turn of mind, the distribution of the costs and benefits that stem from liberalization may be just as important as the net benefit to society, and they will not look favourably on a policy for which the disparities are seen to be too great.

Some modern scholars share Smith's views. For example, Baumol's own definition of a "superfair" outcome in debates over public policy depended on no class of participants feeling envy for the shares obtained by another group. More broadly, the field of behavioral economics challenges some of the fundamental assumptions that underlay microeconomics, the theory of the firm, and - as discussed here - political economy. While the standard notion of man as homo economicus sees people as bundles of selfinterest, behavioral economists examine social, cognitive, and emotional factors to find extensive support for the proposition that, in practice, people care about the welfare of others. And in the field of political science it is notable that Schattschneider, who is best known for his essentially Ricardian explanation of the politics behind the (US) HawleySmoot Tariff Act of 1930 (as discussed below), later adopted a perspective that complements Smith's. He came to believe that "[t]he central political fact in a free society is the tremendous contagiousness of conflict" and that the "spectators are an integral part of the situation, for, as likely as not, the audience determines the outcome of the fight" (1960: 2; emphasis in original). In contrast to his analysis of Hawley-Smoot, in which the protectionist outcome was determined by rent-seeking interests that operated on a principle of "reciprocal non-interference," Schattschneider's later work described a democratic system in which citizens help determine the results even on matters in which they have no direct interests.

\section{David Ricardo and the Sectoral School}

In contrast to the sociotropic view, the other two schools of thought examined here assume that individuals and those who represent them are more narrow-minded and will act according to what they perceive are their own interests in an issue. For our purposes, the main difference between the Ricardian and Stolper-Samuelson approaches is in how closely wedded individuals are assumed to be to the industries or specific firms in which they are currently employed.

In the framework first advanced by David Ricardo (1821), ${ }^{6}$ a country that opens up to trade raises the real returns to specific factors in its export industries and lowers them in import-competing industries. ${ }^{7}$ Ricardo illustrated the theory of comparative advantage by

6. Modern economists customarily call this the Ricardo-Viner model. In view of the fact that Jacob Viner's contributions to the model were not central to the issues discussed in this note, however, and for the sake of simplicity, we will refer here only to the original proponent.

7. It should be stressed that modern economists do not universally endorse Ricardo's industry-level focus. They have increasingly shifted their attention from industries as a whole to the firms that comprise them, acknowledging that these firms may vary greatly in their efficiency and competitiveness. Drawing on prior work by Krugman (1980) and Hopenhayn (1992), Melitz (2003) started from the assumption that firms within an industry are heterogeneous. His model showed how exposure to trade induces only the more productive firms to enter the export market, confining some less productive firms to the domestic market and forcing the least productive firms to exit altogether. Further exposure to trade will lead to additional inter-firm reallocations towards more productive firms. The aggregate industry productivity growth generated by the reallocations contributes to a welfare gain. In a Melitzian world, a worker should do well if his or her firm is one of the exporting winners, perhaps enjoying a wage premium, and may suffer if he or she has the misfortune to be employed by one of the losers. As important as this shift from an industry- to a firm-level focus is, the Melitz model may still — for purposes of our present analysis — be seen 
explaining how both England and Portugal would be better off if England made the cloth, Portugal made the wine, and the two countries traded these commodities with one another. The net gains for both countries and their consumers are clear, but there are also losers in the transaction: Free trade should be unpopular among English wine producers and Portuguese cloth producers. Or to state the matter more expansively, in a Ricardian world we should expect political actors to associate their own interests with those of the industry in which they are currently invested or employed, with those stakeholders in trade-dependent industries (e.g. competitive exporters, shippers, bankers, producers that are dependent on imported inputs, etc.) usually taking a pro-trade view and stakeholders in less competitive industries doing just the opposite.

The Ricardian model is based on an assumption that commonly underlies most discussions of the political economy of trade. Whether they state it explicitly or adopt it implicitly, analysts and commentators typically assume that people will act as if their ties to specific industries are permanent. This then implies that trade liberalization depends on the relative political strengths of the pro-trade winners vis à vis the import-competing losers. If the industries opposed to trade liberalization are sufficiently large and politically active, they may be able to deflect liberalization in their sector, to block it altogether, or to bargain for some form of compensation.

The mobility of factors of production, especially capital across borders and labour within them, is a critical issue. The Ricardian model is especially persuasive when there are major barriers to mobility. If the owners of capital find it difficult to establish production in another country, and if it is relatively difficult for workers who lose their jobs in one industry to find employment in another, then the interests of both capital and labour in any given industry (whether pro- or anti-trade) should be stable and congruent. The employers and the employees in the British cloth industry should want free trade with Portugal, just as we should expect both capital and labour in the British wine industry to take a protectionist stance. If barriers to foreign investment are lowered, however, and/or labour is relatively mobile across industries, and/or there is a high level of (or potential for) off-shoring of jobs, then the arguments for a Stolper-Samuelson perspective may become more persuasive.

\section{Stolper-Samuelson and the Factor-Endowments School}

The Stolper-Samuelson theorem (1941) builds upon Heckscher-Ohlin's predictions of what countries will trade ${ }^{8}$ to forecast how the gains from trade will be distributed domestically. It holds that open markets will lead to more exports of goods that incorporate factors that are locally abundant and thus will raise the rate of return to those factors. This implies that when a wealthy country with an abundance of skilled labour trades with a poorer country with an abundance of unskilled labour we should see higher wages paid to skilled labour in the wealthy country and to unskilled labour in the poorer country. The losers under Stolper-Samuelson are unskilled labour in the wealthy country and skilled labour in the poorer country.

as a more nuanced and disaggregated version of the Ricardian model, rather than as a fundamental departure from it, insofar as it implies that the interests of employers and employees are still congruent.

8. The Heckscher-Ohlin model predicts that countries will import goods that incorporate factors that are less abundant at home and export goods that incorporate the locally abundant factor. 
The political conclusions that stem from this theorem may be even more consequential than its still-contested economic lessons, as it appears to give credence to the concerns often expressed by organized labour in the industrialized countries. That may be one reason why many pro-trade economists have argued against the theorem on both theoretical and empirical grounds, ${ }^{9}$ and are encouraged when empirical evidence suggests that North-South trade has fewer negative effects in the real world than the theorem would predict. ${ }^{10}$

The differences between the Stolper-Samuelson and Ricardian models are often reduced to class conflict, such that free trade is seen to benefit the haves while hurting the have-nots in the wealthier countries. In a more nuanced reading of Stolper-Samuelson we might expect some stakeholders in a given industry to be less committed to free trade than the owners of the firms in that industry, and others to be less opposed to it than their employers. Workers in an uncompetitive industry may be more prepared to deal with free trade than the companies that employ them if the workers in question have marketable skills and labour is mobile within the economy. Consider again the classic example of wine and cloth, disaggregating the Portuguese industries on Stolper-Samuelson lines. Can a farmer grow grapes on the same land that has heretofore been used to produce cotton or wool? Would a loom-worker with skilled hands be as well paid if he instead mashed grapes with his feet? Can a supply-chain manager be just as adept at the grape-to-wine links as the cotton-to-cloth transformation? Those who answer "no" to these questions illustrate how the Ricardo/Stolper-Samuelson division can be a distinction without a difference, but if any of them answer "yes" and accept liberalization (whether resignedly or enthusiastically) we might take that as evidence of a Stolper-Samuelson worldview.

In the most typical formulation of Stolper-Samuelson divisions within an industry, however, firms are more likely than many of their workers - especially those at the bottom - to favour trade liberalization. That may be especially true for firms that have, or hope to have, transnational operations. If the Stolper-Samuelson model is right, we should expect a firm that currently or prospectively engages in off-shoring to favour trade liberalization, and that the views of its workers will be divided between those who are at high risk of losing their jobs versus those whose jobs are considered safe. The more vulnerable workers, and hence the ones most likely to have views opposed to those of their employers, will generally be those less-skilled, lower-educated workers whose tasks might most easily be assigned to lower-wage workers in a developing country.

9. Some question the theoretical basis of the theorem; see for example Abrego and Edwards (2002) and Davis and Mishra (2007). Others argue that the facts on the ground do not bear out its expectations. Feenstra (2010) has shown that employment and relative wages for skilled workers vis à vis less-skilled workers have risen in both developed and developing countries; these results were consistent with Stolper-Samuelson predictions for developed countries, but not for developing ones. For a more favourable view see McCulloch (2006).

10. The rapid rise in import competition from developing countries has produced a spirited debate among economists over the extent to which this trend is linked to the concurrent decline in the relative returns to unskilled labour in developed countries, and whether we are now observing the Stolper-Samuelson effects of globalisation. See for example the contending views of Krugman (2008), who believes that these chickens have now come home to roost, and Lawrence (2008), who does not. 


\section{Empirical studies of how political actors approach trade policy}

So much for the theory. What do empirical studies tell us about practice? What follows is a review of numerous studies in which political scientists, economists, and other analysts have sought to determine how people and policy makers actually approach the issues of trade and employment. This review concentrates on different manifestations of endogenous tariff theory, ${ }^{11}$ especially those that are based on domestic political actors' ideas and actions with regard to their own interests (either narrowly or broadly defined). The endogenous theories can be divided into those that focus on the demand for protection (i.e. the interests of the private sector) and the supply of protection (i.e. the willingness of state institutions to satisfy these demands). We look below at three general classes of demand-side studies, these being focused on individuals, industries and interest groups, and labour unions. Those three types generally correspond to the Smithian, Ricardian, and Stolper-Samuelson schools of thought, respectively, but the associations are not always tight. We then turn to the supply side, showing how policy makers may respond to the demands made upon them by domestic interests. Supply-side studies point to additional factors that policy makers might weigh, such as considerations of foreign policy and ideology, and thus modify their responses to the demands they receive from civil society.

\section{The Demand Side I: The concerns of worker/consumer/voters}

We start with individuals, who are always consumers, usually workers, and often voters. Acting in these capacities, and especially as voters, do they tend to behave according to their perceived self-interests or with a view towards the larger needs of their community? Several analysts have addressed this question by examining surveys of public opinion and/or the voting behavior of citizens.

There is no doubt that the economic performance of government matters to the public, and that performance is often measured by the level of employment. As Di Tella et al. found in their review of survey data for Europe and the United States, "macroeconomic movements have strong effects on the happiness of nations" and "recessions create psychic losses that extend beyond the fall in GDP and rise in the number of people unemployed" (2003: 809). Except perhaps in times of hyperinflation or all-out war, the unemployment rate is the most common metric by which the public at large evaluates the performance of government. "When economists think about the labour market effects of trade (and globalisation more generally), we think about wages," Davidson et al. (2010: 1) admitted, but "when everyone else thinks about the labour market effects of trade (and, by all accounts, they do), they think about jobs." Survey evidence confirms that voters are far more concerned about, and more aware of, unemployment than inflation. Using data from the Euro-Barometer Survey Series, for example, Di Tella et al. estimate that "people would trade off a 1-percentage-point increase in the unemployment rate for a

11. Exogenous tariff theory, which holds that a country's trade policy can be understood primarily as a function of external causes, is outside the scope of this inquiry. Many of the exogenous approaches are variations on the theory of hegemonic stability, a paradigm that is widely though not universally accepted among scholars of international political economy. It asserts that the openness of the global economy depends critically upon the presence of a hegemonic power that has both the motive and means to establish a liberal trading order (see Kindleberger, 1973; Krasner, 1976; and Gilpin, 1987). That theory offers a framework for understanding why markets are sometimes open and sometimes closed, but at a "big picture" level that is not useful for our present purposes. 
1.7 percentage point increase in the inflation rate" (2001: 340). Similarly, Conover et al. (1986) found lag times in the public's learning of economic trends, reacting more quickly to changes in unemployment than inflation.

The fact that unemployment matters is not surprising, nor that it matters more than other numbers, but the meaning of these twin facts may be in dispute. Do people see jobless data through a mirror or a window? When Citizen Smith is told that the unemployment rate is rising does she fear for her own job, feel bad for those who have lost theirs, or both?

There is evidence here that points to sociotropic leanings in the general public. In a review of voter attitudes towards the US presidential election of 1984, for example, Mutz and Mondak found that "voters are substantially more likely to judge the president favourably if they feel that class groups have enjoyed similar rather than dissimilar changes in economic performance" (1997: 284). Speaking more directly to trade, Mansfield and Mutz (2009) found strong evidence that the US public is guided less by the material self-interest of individuals than by perceptions of how trade affects the economy as a whole. Davidson et al. (2010: 31) concurred, finding that there is "considerable evidence that, when citizens think about trade policy, unemployment plays a major role in their calculation and that this calculation contains a major sociotropic element." Stiglitz and Charlton (2005) also concluded that considerations of fairness have long played a significant role in shaping trade policy.

The divide between a Smithian/sociotropic view and a more self-centered perspective, whether of the Ricardian or Stolper-Samuelson variety, may be partly a matter of political culture. That seems to be the implication of the many authors who contrast the political culture of the United States, which is variously associated with "rugged individualism" (as supporters would have it) or "savage capitalism" (as detractors sometimes put it), with other, arguably more communitarian societies such as Canada (e.g. Horowitz, 1966), Europe (e.g. Pontusson, 2005), and Japan (e.g. Verbal et al., 1987). If US political culture is indeed more individualistic then that of other wealthy democracies, the evidence cited above for sociotropic sentiments and behavior on the part of US voters should be considered all the more significant. The extent of that influence in the United States nonetheless remains a matter of interpretation and dispute. On the one hand, Conover et al. (1986) argued that sociotropic voting may be more apparent than real, insofar as individuals' perceptions of national economic conditions may be heavily influenced by their own circumstances. On the other hand, Funk and Garcia-Monet responded to these claims with a study that found only weak evidence for such a connection. "While personal and collective experience cannot be completely divorced," they argued (1997: 317), "political judgments derive largely from collective-level considerations which are quite separate from personal economic experiences."

Even if we conclude that sociotropism is real and significant, however, it does not necessarily follow that this is the only way that non-economic thinking affects debates on economic policy, nor that these considerations either undo or are unrelated to individuals' regard for their own interests. Consider the results of O'Rourke and Sinnott's comparative and cross-national review of survey data. They found that "protectionist attitudes are strongly related to both patriotism and chauvinism" (2002: 185), two phenomena that do not square well with sociotropic ideas. Their data also tended to indicate the presence of a Stolper-Samuelson worldview (though they preferred to identify it with Heckscher-Ohlin), noting that "in countries with per capita incomes below 
USD 12000 , the lowest skilled tend to be more in favour of free trade, while they tend to be more protectionist in countries above that income threshold" (ibid.).

Other reviews of public opinion also point towards a Stolper-Samuelson interpretation. The "globalisation backlash" reflects widespread skepticism among US citizens, according to Scheve and Slaughter (2001a), and these perceptions seem to be closely connected to the labour-market pressures on US workers. This is shown in public opinion surveys indicating that citizens recognize both the costs and benefits of integration with the world economy, and that they tend to give greater weight to the costs than to the benefits. They found that less-skilled workers are much more likely to oppose freer trade and immigration than their more-skilled counterparts. In another study, Scheve and Slaughter (2001b) used a data set that identified both the stated trade policy preferences of individuals in the United States in 1992 and their potential trade exposure. They found that factor type is more important than industry of employment in explaining support for trade barriers, and that home ownership in counties with a manufacturing mix concentrated in comparative disadvantage industries is strongly correlated with support for trade barriers. Preferences thus depend not only on skills but also on asset values.

In sum, the data regarding the attitudes of individuals towards trade policy are subject to interpretation. Depending on how one frames the question, in what countr(ies), and with what kinds of evidence, the results might variously provide support for positions based on self-interest (especially in Stolper-Samuelson terms), or for views that are modified by sociotropic sentiments, or that are influenced by other non-economic considerations (e.g. nationalism), or that amount to an enlightened self-interest that only appears to be affected by non-economic considerations.

\section{The Demand Side II: The conflict between interest groups}

Economic determinism is the most traditional approach to explaining how trade policy is made. Almost by definition, we can expect a study that focuses on interest-group politics to start from a Ricardian perspective and to be based on a principal-agent mechanism in which legislators and other policy makers (agents) merely represent the interests of their constituents (principals). Those principals are assumed to define their interests in narrow, economic terms, usually in line with the industries that employ them. In a democracy, agents who fail to deliver the goods may soon find themselves out of a job, as principals will exercise electoral retribution upon them. This school of analysis dates as far back as Smith's declaration that the monopolies in favour of trade restrictions had become "like an overgrown army" that "upon many occasions intimidate the legislature" (1776: 471).

Schattschneider's account of how the US Congress drafted the protectionist HawleySmoot Tariff Act of 1930 remains the classic statement of Ricardian parochialism. Arguing that "the nature of public policy is the result of 'effective demands' upon the government" by organized interest groups (1935: 4), he found that congressional committees left the initiative to the lobbies and that protectionist industries took full advantage of the opportunity. The author of the present note found that while US trade policy was notably more liberal in the 1980s and the 1990s than it had been in 1930, this shift in policy stemmed more from changes in what industry wanted than from how policy makers responded to these demands (VanGrasstek, 1997). Some analyses take it for granted that protection is doled out to those who appeal for it. The key question then becomes why industries choose to lobby and what factors contribute to their success. For example, some contend that geographic concentration facilitates an industry's lobbying 
by facilitating their efforts to organize themselves (Pincus, 1977; Anderson and Baldwin, 1981), while others hold that geographic dispersion strengthens an industry by giving it a voice in multiple constituencies (Magee et al., 1989); Schonhardt-Bailey (1991) found that both concentration and deconcentration of interests served to push Britain towards liberalization in the mid- $19^{\text {th }}$ century.

It is not difficult to find evidence that firms, industry associations, and other economic interests make demands on legislators and other policy makers, and it often takes only a little more effort to come up with descriptive or inferential statistics that show correlations between these demands and policy. Two related questions, however, can be more difficult to answer. One of them, as taken up in a later section, is whether policy makers' responses are modified through the consideration of other factors such as personal ideology or the imperatives of foreign policy. Another tricky question is whether the links between demands from the private sector and governmental responses can best be characterized in Ricardian or Stolper-Samuelson terms. While the former explanation is more prominently represented in the literature, there are some analysts who find support for the latter. Rogowski (1989), for example, used the Stolper-Samuelson theorem to suggest that we look to lobbying capitalists to find a political economy explanation for extraordinarily high Latin American tariffs. In another study published that same year, Magee et al. posited an "endowment effect" whereby the "equilibrium tariff increases with the square root of the ratio of the country's scarce factor to its abundant factor" (1989: 25). Stolper-Samuelson considerations may also affect the positions taken by legislators on related issues. ${ }^{12}$

The validity of a Ricardian versus a Stolper-Samuelson outlook depends largely on the degree of mobility in the factors of production. In his review of multiple episodes in numerous Western societies during the $19^{\text {th }}$ and $20^{\text {th }}$ centuries, Hiscox (2001) found that "class-based parties and peak associations are more unified on trade ... when levels of [factor] mobility are higher," but that "[i]ndustry coalitions appear stronger ... when levels of factor mobility are lower" (2001: 34). In other words, either a Ricardian or a Stolper-Samuelson explanation could work, depending on the prevailing conditions at a given time. It may also depend on the nature of the goods being traded. Williamson (2003) argued that "Stolper-Samuelson has a far better chance of explaining $19^{\text {th }}$ century tariff policy when, after all, most trade was in primary products and (immobile) specific factors played a big role," but "has a far poorer chance of explaining late $20^{\text {th }}$ and early $21^{\text {st }}$ century tariff policy when trade has shifted to manufactures and most factors labour, skills and capital — are mobile" (10-11).

\section{The Demand Side III: The Objectives of Labour Unions}

This then brings us to labour unions, which can be seen as a special case among studies of interest-group politics. If the Ricardian approach is dominant among analyses of interest-group activism in general, the perspectives on the political economy of labour unions and trade are often driven by Stolper-Samuelson considerations.

12. In his examination of votes in the US Congress on the financial rescues of Mexico and several Asian economies in the 1990s, for example, Broz (2002) followed Stolper-Samuelson reasoning to find that a House member was significantly more likely to oppose these bail-outs as the proportion of low-skilled workers in the district increased. 
While Smith himself was more sympathetic to labour than some might expect, ${ }^{13}$ many later economists have taken a darker view of unions. What is at stake here is a special case in the immobility of factors of production. In contrast to the "natural immobility" that comes from highly specific skill sets, unions may seek to create an artificial immobility both domestically (through barriers to entry and exit that favour union members) and internationally (through the maintenance of existing trade restrictions or the imposition of new ones). Lindblom bluntly asserted that "unionism and the private enterprise economy are incompatible" (1949: v), and Olson (1982) saw unions and other organizations in civil society as members of rent-seeking "distributional coalitions" that operate to the detriment of society as a whole and cause nations to decline. Others have less dramatically reduced the issue to one of equality versus efficiency (e.g. Okun, 1975), often coming down more on the side of the latter than the former. Bennett and DiLorenzo (1980) characterized unions not as instruments of collective bargaining but instead as agents of redistribution that seek to benefit some members and union leaders at the expense of other members, non-union employees, and consumers.

There are nonetheless some political economists who take a more favourable view of unions. At least one author contended that unions are not necessarily as protectionist as are their employers. Wallerstein concluded that unions "are foul weather allies in protectionist coalitions," insofar as his model showed they "will support their employers in attempts to gain increased protection (or regulation or subsidies) when union members are threatened with unemployment but not when the industry's work force is expanding beyond the existing union membership" (1987: 748). In a game-theoretic model, Palokangas argued that countries in which unions are powerful tend to import primary products and export refined products, and that it therefore "follows that real output growth is faster in countries with relatively high union power" (2000: 5).

The impact that unions have on trade policy depends in part on the extent to which they are organized and effective. In his review of the relations between capital and labour in Britain during the period between the two world wars, Garst (1999) argued that weak trade union organization modified the incentive of business owners to align with labour on trade, even when imperfect capital mobility and divisions in the business community heightened the incentive of capitalists to form lobbying coalitions with labour. He concluded that these factors explained why pre-World War I Britain was unique in Western Europe for its strong business-labour collabouration over trade and political reform.

While labour unions may influence the direction of trade policy, the causation could also move in the opposite direction. Baldwin (2003) found that increased trade seems to have contributed, albeit modestly, to the general decline in unionization in the United States. Between 1977 and 1997 the share of US workers with median education who were represented by a labour union fell from $29 \%$ to $14 \%$, but the decline was less steep among workers with above-median education (from 19\% to 13\%).

Nearly all of the studies noted above stress the self-interested nature of unions, sometimes contrasting their goals with the greater good of the public. One might nevertheless find some support for a Smithian/sociotropic view in countries where there is sympathy for labour in general, and/or labour unions are well-regarded by the public. This is among those questions where political culture matters, as countries differ in where the median voter would situate unions along the spectrum of essential to pernicious. In a

13. See Book I, Chapter VIII ("Of the Wages of Labour") of The Wealth of Nations. 
review of four Swedish cases from the 1920s through the 1970s, for example, Pontusson (1993) found evidence that the politics of reformism are shaped by the extent to which the initiatives are perceived to embody a universalistic conception of social justice or alternatively appeal to the material interests of swing voters. Using a model that captures government's sympathy to trade-affected workers, Yotov (2010) offered empirical evidence that the US government is very sensitive to the presence and the magnitude of trade-induced unemployment, with office-holders attaching four times as much weight to the welfare of trade-affected workers compared to the welfare of those who are not affected by trade.

\section{The Supply Side: How policy makers sort out these demands}

The three approaches to demand-side policymaking reviewed above generally assume that policy makers in the executive or legislative branches of a government are mere agents of their principals. An altogether different set of analyses treat these policy makers as semi-independent actors who - in addition to soliciting the views of the private sector - may also be swayed by other economic, ideological, partisan, diplomatic, or security considerations. These pressures may tend either to counteract or to bolster the demands of industries, sometimes pressing elected officials and civil servants in directions that we would not expect from a purely principal-agent model of policymaking.

One variation on supply-side theory stresses the importance of ideology - Keynes' aforementioned "ideas of economists and political philosophers" - as a check upon parochialism. Liberal economic ideas have become so widely accepted in policymaking circles, it is argued, that policy makers will not seriously consider a return to antiquated policies. The state is not merely a captive of private interests, by this view, and policy makers may believe it is their duty to execute good public policy even in the face of contrary pressure from special interests. The ideological argument takes two different forms. One suggests that liberal trade ideas are essentially complementary to the pressures brought by pro-trade industries, and thus serve to reinforce but not create the environment in favour of continued openness. Destler and Odell's analysis of antiprotectionist forces in the United States offered a good example of such modest claims, arguing that policy makers preferred open to closed markets and welcomed the lobbying of pro-trade interests because "[p]ublic evidence that protection would hurt other citizens gives liberal-leaning leaders political support they feel they need ... to deny or water down the request" to impose restrictions on imports (1987: 101). A few analysts suggest that ideas have much greater persuasive force. In her examination of US trade debates in the $19^{\text {th }}$ and $20^{\text {th }}$ centuries, Goldstein found that "ideas $\ldots$ become predictors of the direction of policy at least as powerful as are simple calculations of interest" (1993: 3). In this view, protectionist policies represent not the policy maker's failure to recognize the superior benefits of economic liberalism, but are instead a competing philosophy of public policy.

Another theory rests on the dominance of the executive branch in foreign policy. In the United States trade policy was a virtual monopoly of Congress prior to the 1930s, but has since been based principally upon laws by which the legislative branch delegates authority to the executive. Bauer, Pool, and Dexter (1963) argued that this delegation of authority effectively transformed trade policy into an arm of foreign policy. Liberal trade initiatives were an important component of Cold War internationalism, displacing the discredited policies of isolationism and protectionism. Lowi crystallized their thesis by declaring that the outcome of a policy debate will depend "upon whose definition of the situation prevailed. If tariff protection is an instrument of foreign policy and general 
regulation for international purposes, the anti-protectionists win; if the traditional definition of tariff as an aid to 100,000 individual firms prevails, then the protectionists win" (1963: 682-683). Pastor (1980) and Destler (1992) incorporated similar arguments in their analyses of congressional trade politics. More recently, Milner and Tingley (2010) tested votes in the US House of Representatives from 1979-2004 against different theoretical predictions about foreign economic policy. They found that trade preferences are shaped by the president's foreign policy concerns.

It is reasonable to suppose that policy makers' ability to exercise independent judgment, whether of the ideological or foreign-policy variety (or some combination), will vary according to the economic profile of trade - and hence the political profile of trade policy - in a given country. As a general rule, larger and more economically diverse countries tend to be less trade-dependent than are smaller countries. In the United States, for example, trade in 2009 was equivalent to $25 \%$ of GDP, versus $48 \%$ in France, $85 \%$ in Costa Rica, and $147 \%$ in Vietnam. ${ }^{14}$ The weight given to economic versus noneconomic considerations may also vary according to the place of a country in global affairs. Consider the difference between the United States, which has the world's largest military, and Costa Rica, which has no military at all. It should not come as a shock if US and Costa Rican policy makers were to differ in the extent to which they sought to use trade policy as an instrument of foreign policy, with the superpower considering trade a useful political tool and the smaller country being more interested in trade for its intrinsic economic value. For both economic and non-economic reasons, therefore, we might expect policy makers in countries that are more powerful and/or less trade-dependent countries to enjoy higher levels of independence from the sectoral interests of voters than do their counterparts in weaker and/or more trade-dependent countries.

A recent pair of related studies speaks to this proposition. When Guisinger (2009) tested the extent to which US voters held Senate incumbents accountable for their 2005 vote on the US-Central American Free Trade Agreement (CAFTA), she found that (compared to roll call votes on other issues) the salience of trade policy was relatively low in terms of stated importance, in voters' knowledge of their representatives' policy positions, and in its effect on voters' propensity to vote for the incumbent. "The low salience of trade policy," she concluded, "particularly among highly affected groups, calls into question voter-driven models of trade policy" (2009: 533). By contrast, CAFTA was a high-profile issue in Costa Rica, where it was the subject of a national referendum. That does not mean that voters saw the issue in purely economic terms, however, as Milner et al. (2010) found surprisingly little support for Stolper-Samuelson models of economic preferences. Ideology mattered in Costa Rica as well, but did so by way of sentiment in the general public rather than solely among governmental elites. Taken together, these two CAFTA-related studies suggest that we should not be quick to devise universal rules regarding the extent to which national decisions on trade agreements are based on considerations of sectoral interests, ideology, or foreign policy, as the results may well differ according to country and context.

\footnotetext{
14. Calculated from World Bank data downloaded data.worldbank.org/indicator/NE.IMP.GNFS.ZS (imports) and data.worldbank.org/indicator/NE.EXP.GNFS.ZS/countries (exports) on 8 March 2011. Note that trade can exceed the total value of GDP because GDP is calculated on the basis of net exports rather than total trade. Note also that while all of these 2009 values were suppressed somewhat by the decline of trade during the Great Recession the relative ranking among countries was not much affected.
} 
Timing also matters, as it has long been an accepted point of trade negotiators' folklore that one cannot present major agreements for domestic approval during election years. Initiatives therefore need to be timed according to the "windows of opportunity," which is generally taken to be those years in which there are no national elections scheduled in any of the largest democracies. The author of the present note has not, however, found any studies that formally test this proposition. ${ }^{15}$

The discussion thus far has indicated ways that policy makers might distance themselves from the demands of industries and other economic interests, but we should also consider the ways that industries might attempt to wield influence that extends beyond their apparently natural boundaries. In a democracy where legislators are elected in geographically based districts, we might ordinarily expect industries to be influential only in those districts where their facilities are located. Grossman and Helpman nonetheless advanced a protection-for-sale model in which interest groups make political contributions to influence an incumbent government's choice of trade policy. Starting from the assumption that politicians are "maximizing agents who pursue their own selfish interests rather than as benevolent agents seeking to maximize aggregate welfare" they argued that "the manner of campaign and party finance in many democratic nations creates powerful incentives for politicians to peddle their policy influence" (1994: 848). A legislator who represents a district in which there is no steel production, for example, might nonetheless be willing to vote in favour of import protection for this industry if campaign contributions from steel producers make that worth his while.

This represents yet another way in which the political economy of trade policy may differ across countries, depending inter alia on their constitutional systems and campaignfinance laws. For example, Matschke (2004) found that the greater labour market rigidities that are prevalent in continental European countries, such as influential trade unions and high unemployment benefits, render the Grossman and Helpman model less applicable because these rigidities do not necessarily increase equilibrium trade protection.

\section{Policy options for open markets}

No matter which school of thought one follows, it is widely accepted that trade liberalization has both costs and benefits. What should be done about those costs? At one extreme lies an essentially Darwinian or Schumpeterian response: Whether we choose to call it survival of the fittest or creative destruction, liberalization brings about greater competition that will inevitably produce losers as well as winners. Society as a whole, it may be argued, would be better off if those resources (human and other) that are poorly employed were to be reallocated to other, more productive undertakings. The disruptions that some may suffer should, under this reasoning, be seen as a small price to pay for the greater good of society. At the other extreme, if we were to place a high value on the interests of the losing industries and their workers we might forego the benefits of liberalization either partially (by adopting policies that limit liberalization or inhibit full

15. One may also come up with anecdotal examples of agreements that violated this supposed law with impunity. The US Congress approved the US-Canada Free Trade Agreement, which is the single largest such agreement in the world, just weeks before the presidential and congressional elections of 1988. That same year the agreement became the central issue in the Canadian parliamentary elections, and while the ruling Conservatives lost seats they retained their majority and thus managed to implement the agreement. 
adjustment to it) or completely (by not undertaking the trade reforms at all). There is much ground that separates a pure sink-or-swim policy from a risk-averse avoidance of liberalization, but it can be difficult to strike that happy medium at just the right point. As Melitz noted, in liberalizing trade it is important "to design accompanying policies that would address issues related to the transition towards a new regime," but "policies that hinder the reallocation process or otherwise interfere with the flexibility of the factor markets may delay or even prevent a country from reaping the full benefits of trade" (2003: 1719).

Several options are discussed below. These alternatives are not necessarily mutually exclusive, but do imply differing ways of conceiving of the underlying problem and devising solutions to it. They are closely related to the three main schools of thought laid out above.

\section{Public diplomacy}

The simplest approach of all is to counter concerns over the costs of liberalization by ensuring that the public is made equally aware of trade's benefits for exporting industries, the net positive consequences for consumers and the economy as a whole, and (as discussed below) any programs that may be in place to assist displaced workers. This is an approach that is based upon the assumption that many people do indeed take a sociotropic view of public policy, and will be receptive to appeals that stress the positive aspects of trade liberalization for society as a whole.

Studies of public attitudes toward trade tend to confirm that support for trade restrictions is highest among respondents with the lowest levels of education, a point that some interpret as strong evidence for the Stolper-Samuelson theorem (i.e. less educated and therefore less skilled persons perceive that they would fare poorly in a more open market). Hainmueller and Hiscox (2006) nevertheless reported survey data showing that the impact of education on attitudes toward trade is almost identical among respondents who are in the active labour force and those who are not, thus casting doubt on the association between education and self-interest. They found that exposure to economic ideas and information among college-educated individuals plays a key role in shaping attitudes toward trade and globalisation. This points to an irony: Academic economists can be effective salesmen for those policies that they believe are in the best interests of the public, but their persuasiveness may depend on the public thinking in sociotropic ways that violate the typical assumptions of the economists.

If education matters in the long term, is it possible in the short term to use public diplomacy as a means of better informing the public of the benefits of trade? This might be especially useful if the public is indeed sociotropically inclined but tends to overestimate the costs and/or underestimate the benefits of free trade. The gap between the public's negative beliefs and the more positive message from economic studies might be filled by public-information campaigns that are sponsored or conducted by government, non-governmental organizations, think tanks, international organizations, or other advocates.

There are two potential problems with this approach. The first is that individuals may be resistant to "jaw-boning" from the government in general: One man's public diplomacy is another man's propaganda or spin. Second, a study suggests that messages on trade in particular may face an uphill struggle. Using survey data on American adults, Hiscox (2006) compared the views expressed on trade by those who were variously read a statement with a pro-trade introduction (referring to job creation and consumer choice), 
those who were read an anti-trade introduction (referring to job loss and unfair competition), or were read both of these statements, or were give no introduction at all. Those subjects who were given the pro-trade introduction were no more likely to support trade liberalization than those who were given no introduction, meaning that the positive economic appeal had no discernible effect, but those who were read the anti-trade introduction (with or without the pro-trade introduction) were significantly more likely to oppose freer trade. This appears to imply that the opponents of trade liberalization may enjoy an advantage in any "air war" over the issue. It further suggests although public attitudes may be affected by the long-term effects of education, a short-term pitch offers a poor substitute.

\section{Structuring trade agreements to meet industry demands}

Another approach, this time founded upon Ricardian principles, is to conduct trade negotiations in ways that reduce the likelihood or intensity of opposition at home. The most import-sensitive industries might be self-identified (e.g. through responses to a government's call for comments, testimony at public hearings that might be held by legislative committees, inter-agency committees, etc.), or indicated through the studies conducted by governmental investigative bodies, or both. Those same methods might also be used to identify those industries that depend upon imports for their inputs, or face barriers to exports in other markets, or are in the process of moving production off-shore, or otherwise have characteristics or are undergoing changes that should be factored into the process by which the country's statesmen prepare for and engage in negotiations.

There are several ways that the interests of import-sensitive industries can be taken into account in a trade negotiation. The most obvious is to keep their products "off the table" entirely. Commitments made on sensitive products might be made more palatable through smaller cuts, slower phase-in schedules for any reductions, tariff-rate quotas, and "snap-back" mechanisms. Another variation on this approach is to provide for means by which countries' commitments in an agreement might later be modified. These include provisions that allow for the renegotiation of commitments, safeguards that can be imposed against fair but injurious increases in import competition, or the imposition of antidumping or countervailing duties on imports that are found to be both unfairly traded and injurious.

These approaches all have their attractions, as demonstrated by the fact that they are widely used. "[I]n the real world," as Giordano (2009a: 16) noted, trade agreements "are invariably drafted under mercantilist pressures." The frequency with which negotiators fall back on such devices does not, however, mean that they are optimal. One obvious drawback is that they tend to undercut the intended purpose of the negotiation by preventing liberalization, diluting it, or making it contingent and uncertain. Another problem is that results of the negotiations can, after many iterations, produce tariff schedules that are imbalanced and distorted through tariff peaks and tariff inversions. In the present circumstances, perhaps the most serious problem is that this approach can produce a negotiating environment that makes it all the more difficult for countries to "get to yes." The first decade of negotiations in the Doha Round - and the very fact that one can now use the phrase "the first decade" is quite telling - appears to have been dominated more by some countries' efforts to protect their defensive interests than by their efforts to advance their offensive interests. At an absolute minimum, it can be stated without fear of contradiction that the negotiations have gone on far longer than is ideal. They might also result in a final package of commitments that only a true optimist would call ambitious. 
One solution worth considering is whether efforts might be made to encourage greater activism on the part of pro-trade interests. Unlike the public-diplomacy option discussed above, which would urge individuals to rethink what is in their best interests, this approach would be based upon encouraging firms and industry associations to be more vocal about expressing their interests. It may be that in some countries the industries with defensive interests are more motivated, politically connected, and effective than are the industries that favour liberalization, whether on the import or export side. That may well be the case when the protected industries are acutely aware of how precarious their position is, perhaps because they have had to fight for protection repeatedly, but some potential winners are not even aware yet that they could be exporters, and others that benefit from liberalization (e.g. retailers) have not overcome the public-goods barriers to organization and activism. It may be possible that the net pressures could be shifted if a more concerted effort were made to inform the pro-trade side about what is at stake and how they might help the government help them.

One way of achieving this end is to structure international negotiations in ways that encourage a more pro-trade orientation in the domestic policy. One of the reasons why what were then known as the "new issues" of services, investment, and intellectual property rights were put on the table in the 1980s was to encourage the reinvigoration of the pro-trade coalition within the United States, replacing some of the older manufacturers that had left that group with new members in the knowledge-based and high-technology sectors. That effort was largely successful, both by bringing many more new supporters than critics into the trade policymaking community in the developed countries and by encouraging the international community to produce a more ambitious agreement. ${ }^{16}$ Unlike the usual pattern noted above, in which negotiators try to make a trade deal more palatable by catering to demands on the defensive side, this approach seeks to up the ante on the offensive side.

\section{Structuring trade agreements to address labour rights}

Another option that countries have tried, albeit with more complex results, is to address the concerns of labour directly in trade agreements. Starting in the 1990s, it has become increasingly common for trade agreements - and especially free trade agreements (FTAs) between developing and industrialized countries ${ }^{17}-$ to include chapters or other sections dealing with labour rights, or to be complemented by related agreements or programs in this area. Among the various measures that one finds in some FTAs or related instruments are requirements that a country enforce its existing labour laws, that it not use violation or relaxation of these laws as a means of attracting investment or promoting trade, the inclusion of labour issues within the disputesettlement provisions of an agreement, the establishment of committees or other institutions by which the parties to an FTA might exchange information or discuss issues

16. The results were not entirely one-sided, as the "new issues" have raised concerns on the part of those who (for example) believe that the enforcement of intellectual property rights results in higher costs for pharmaceuticals or reduce countries' ability to regulate in the service sectors.

17. Labour is off the table in the Doha Round, the ministerial declaration for which reconfirms in paragraph 8 that the International Labour Organization is the competent body for dealing with this issue. There nevertheless are indications that some members of the World Trade Organization would prefer that the issue be more directly addressed in the post-Doha work program of the organization. 
in this area, and the funding of programs intended to improve the living standards of workers or the establishment and operation of labour unions.

Provisions of this sort appear to have both stated and unstated objectives. The explicit goal is to help ensure that the benefits of liberalization are widely spread within the developing countries that are parties to the FTA, with labour gaining as well as capital. The usually unstated objective is to address concerns within the industrialized country that are rooted in Stolper-Samuelson calculations, and to help ensure that the costs of liberalization do not fall heavily on labour. When coupled with other "sweeteners," such as adjustment-assistance programs (see below), this could help persuade some unsure legislators.

One may contrast the political consequences that stemmed from the expanding scope of trade policy in the 1980s with the "newer issues" that came to prominence in the 1990s (i.e. labour rights and the environment). Whereas the introduction of the aforementioned "new issues" of services, investment, and intellectual property rights was generally successful in reinvigorating the pro-trade coalitions in industrialized countries, the consequences of the newest issues have been more complex and controversial. This is especially notable in the United States, where the relationship between trade, labour rights, and environmental protection is a matter of sharp dispute between the two major political parties. Their disagreements on this subject have been one of the principal reasons behind the delays in the approval of some trade agreements (especially the USColombia FTA) and for the difficulties that US presidents have had in obtaining new grants of negotiating authority from Congress. No matter what position one may hold on whether it is appropriate for trade agreements to deal with these issues, and on what terms, it is indisputably clear that the inclusion of labour and environmental issues within the scope of debates over trade policy has not made those debates politically easier to resolve.

\section{Trade adjustment programs}

While each of the options discussed above tends to be associated more with one or another of our schools of thought, there is one approach that might simultaneously appeal to all three: the provision of trade adjustment assistance to workers who are negatively affected by trade. From a Smithian perspective these measures may appear to answer concerns over distributive justice; for a Ricardian, they might be targeted to those industries that need (or demand) them most; and from a Stolper-Samuelson point of view, they may help move workers out of the least-skilled and most vulnerable positions to more competitive pursuits.

Trade-adjustment programs (TAPs) are part of the broader category of policies known as active labour market programs (ALMPs), the main distinction being that TAPs are focused on workers that lose their jobs to import competition and ALMPs deal more broadly with unemployment without respect to the specific cause. In both cases, the actual benefits may include such elements as occupational training, programs to create jobs (directly or indirectly), employment services, encouragement of self-employment and micro-enterprises, etc. TAPs may help to facilitate a transition to the more efficient allocation of resources that should result from the negotiated liberalization of markets, providing inter alia for the retraining of workers who may lose their positions in a declining sector but might be redirected towards a rising one.

There is a lively debate among scholars on the effectiveness of TAPs. Feenstra and Lewis (1994) argued that when all factors of production are imperfectly mobile it is 
necessary to employ policies that give factors an incentive to move, and that TAPs programs can play a vital role in this approach. Pareto gains can result if the government offers a subsidy to all individuals willing to move between industries. Matusz (1994) took a more negative view, however, concluding that policies designed to attract workers to the high-wage sector could result in reduced employment and lower social welfare if the low-wage sector is also the relatively labour-intensive sector. Other analysts examine how TAPs function in practice. In a review of 159 studies of ALMPs, Betcherman et al. (2004) observed a wide range of results, with some programs demonstrating positive labour market effects for participants and others showing either no impact or even negative effects.

This is an area where the policies of major trading countries differ. The European Commission promotes policies that combine flexible labour markets with high levels of social security for the unemployed. Through this policy of "flexicurity" some European countries "have responded to the challenge of adapting their labour-market institutions ... by combining flexible labour regulation with solid mechanisms for protecting the unemployed, including both direct financial subsidies and active labour-market policies" (Weller, 2009a: 16). Programs in the United States focus more on trade-induced job losses, having had a Trade Adjustment Assistance (TAA) program since 1962. In recent years the scope of that program has greatly expanded, with farmers (since 2002) and service workers (since 2009) being brought within its reach. Developing countries also use ALMPs, but the scale of the programs and the resources devoted to them appear to be more limited (International Labour Organization and World Trade Organization, 2007).

TAPs may serve political as well as economic purposes. Those segments of civil society that are concerned over the potential disruptions that might result from trade liberalization, as well as those elected officials who represent the potential losers in the deal, may be inclined to oppose the negotiation, approval, and implementation of marketopening agreements. Basic considerations of distributive justice, as well as rational calculations of practical politics, have thus promoted the notion that TAPs may be needed in order to provide more confidence than might otherwise exist in both the public and private sectors.

Do TAPs achieve their intended political goals? On the one hand, Fung and Staiger (1994) found that TAPs can facilitate reciprocal trade liberalization if the limitations associated with enforcement of trade agreements are sufficiently severe. On the other hand, Davidson et al. (2004) found in a theoretical exercise that although allowing the electorate to vote for compensatory wage or employment subsidies may lead to free trade, placing compensation on the agenda may also block trade if the transfer entailed by compensation is larger than the gains that the winners obtain from liberalization. Using survey data from actual US voters, Burgoon and Hiscox (2008) determined that opposition to trade liberalization tends to weaken support for TAA among the very people who may be most in need of such assistance. They also found that normative values and causal beliefs that underlay the program are partly independent of economic self-interest, and are strong predictors of individual support for TAA. Put another way, the results of this empirical study contradict the expectations of homo economicus in two ways: The data suggest that the program engenders opposition on the part of those whose economic interests would be most directly served by it, but that it derives support from others who are motivated more by ideology than by interest. 


\section{Conclusion}

This review of the literature shows that the political economy of trade and employment has long been, and might forever remain, a matter of deep controversy. There are three principal schools of thought into which most of the participants in the debate can be classified. More than two centuries after Smith's Theory of Moral Sentiments, and nearly as long since Ricardo's Principles of Political Economy, one finds reflections of their views in theory and practice. The age of the Stolper-Samuelson theorem is measured in decades rather than centuries, but is also widely held.

It would be a fool's errand to attempt a simple conclusion on which of these views most correctly captures reality, and to promote axiomatic rules on how policy makers do or should execute their responsibilities. The empirical analyses reviewed here reveal a great diversity in methods, data, and conclusions. At one extreme are those studies that concentrate only on the principals and that, by implication, leave no room for independent thought or action by the statesmen or lawmakers who act as their agents. Whether those principals think and act solely on the basis of self-interest remains a matter of dispute. At the other extreme is the evidence that, in some countries and for some initiatives, trade policy is a reflection of the agents' ideological attachments or an elective instrument of their foreign policy. The observed variation in the characteristics and practices of countries lead us to a conclusion that is safe, inevitable, but not very satisfying: It depends. If one is allowed to choose cases or other evidence freely, one can find data to support or undermine any of the proposed policymaking relationships.

The complexity of relationships between the general public, the private sector, and policy makers should not distract us from the larger point: Concerns over the impact of trade liberalization on employment can affect countries' willingness to engage in that liberalization. That remains true whether these concerns are based on individuals' selfinterest or their concern for others; whether they are worried about what free trade might mean for the industry that employs them or the skill categories into which they fall; whether it is firms or unions that are calling the shots; and whether policy makers merely act on the demands they receive from their principals or they take other ideas and interests into consideration. 


\section{References}

Abrego, Lisandro and T. Huw Edwards. 2002. The Relevance of the Stolper-Samuelson Theorem to the Trade and Wages Debate. CSGR Working Paper No. 96/02. Coventry: Centre for the Study of Globalisation and Regionalisation.

Anderson, Kym and Robert E. Baldwin. 1981. The Political Market for Protection in Industrial Countries: Empirical Evidence. World Bank Staff Working Paper 492. Washington, D.C.: World Bank.

Axelrod, Robert. 1984. The Evolution of Cooperation. New York: Basic Books.

Baldwin, Robert E. 2003. The Decline of US Labour Unions and the Role of Trade. Washington, D.C.: Institute for International Economics.

Bauer, Raymond, Ithiel de Sola Pool, and Lewis A. Dexter. 1963. American Business and Public Policy: The Politics of Foreign Trade. New York: Atherton.

Baumol, William J. 1986. Superfairness. Cambridge: The MIT Press.

Becker, Gary. 1976. "Altruism, Egoism, and Genetic Fitness: Economics and Sociobiology." Journal of Economic Literature Volume 4.

Bennett, James T. and Thomas J. DiLorenzo. 1980. “Unions, Politics, and Protectionism.” Journal of Labour Research Volume 5 Number 3.

Betcherman, Gordon, Karina Olivas, and Amit Dar. 2004. Impacts of Active Labour Market Programs: New Evidence from Evaluations with Particular Attention to Developing and Transition Countries. Social Protection Discussion Paper Series No. 0402. Washington, D.C.: The World Bank.

Broz, J. Lawrence. 2002. "The Domestic Politics of International Bailouts: Congressional Voting on Bailout Legislation in the 1990s." Processed.

Burgoon, Brian and Michael Hiscox. 2008. "Who's Afraid of Trade Adjustment Assistance?: Individual Attitudes on Trade-targeted Adjustment Assistance in the United States." N.P. Processed.

Coase, Ronald H. 1976. "Adam Smith's View of Man." The Journal of Law and Economics Volume 19 Number 3.

Collins, Susan M. and Dani Rodrik, eds. 2002. Brookings Trade Forum 2001. Washington, D.C. Brookings Institution.

Conover, Pamela J., Stanley Feldman, and Kathleen Knight. 1986. "Judging Inflation and Unemployment — The Origins of Retrospective Evaluations." Journal of Politics Volume 48.

Davidson, Carl, Steven J. Matusz, and Douglas R. Nelson. 2004. "Can Compensation Save Free Trade?" N.P.: Processed.

Davidson, Carl, Steven J. Matusz, and Douglas R. Nelson. 2010. "A Behavioral Model of Unemployment, Fairness and the Political Economy of Trade Policy.” Processed.

Davis, Donald R. and Prachi Mishra. 2007. "Stolper-Samuelson Is Dead: and Other Crimes of Both Theory and Data." Chapter in Harrison (2007). 
Destler, I.M. 1992. American Trade Politics second edition. Washington, D.C.: Institute for International Economics.

Destler, I.M., and John S. Odell. 1987. Anti-Protection: Changing Forces in United States Trade Politics. Policy Analyses in International Economics 21. Washington, D.C.: Institute for International Economics.

Di Tella, Rafael, Robert J. MacCulloch, and Andrew J. Oswald. 2001. "Preferences over Inflation and Unemployment: Evidence from Surveys of Happiness." American Economic Review Volume 91 Number 1.

Di Tella, Rafael, Robert J. MacCulloch, and Andrew J. Oswald. 2003. "The Macroeconomics of Happiness." The Review of Economics and Statistics Volume 85 Number 4.

Feenstra, Robert C. 2010. Off-shoring in the Global Economy: Micro Economic Structure and Macroeconomic Implications. Cambridge: The MIT Press.

Feenstra, Robert C. and Lewis, T. 1994. "Trade Adjustment Assistance and Pareto Gains from Trade.” Journal of International Economics Volume 36.

Fung, K.C., Staiger, Robert, 1994. Trade Liberalization and Trade Adjustment Assistance. NBER Working Paper No. 4847.

Funk, Carolyn L. and Patricia A. Garcia-Monet. 1997. "The Relationship between Personal and National Concerns in Public Perceptions about the Economy." Political Research Quarterly Volume 50 Number 2.

Garst, W. Daniel. 1999. "From Sectoral Linkages to Class Conflict: Trade and Coalition Formation in Britain Prior to and After World War I." Comparative Political Studies Volume 32 Number 7.

Gilpin, Robert. 1987. The Political Economy of International Relations. Princeton: Princeton University Press.

Giordano, Paolo. 2009a. "Toward a Propoor Approach to Economic Integration." Chapter in Giordano (2009b).

Giordano, Paolo, ed. 2009b. Trade and Poverty in Latin America. Washington, D.C.: InterAmerican Development Bank.

Goldberg, Pinelopi K. and Nina Pavcnik. 2007. "Distributional Effects of Globalisation in Developing Countries.” Journal of Economic Literature Volume 45 Number 1.

Goldstein, Judith. 1993. Ideas, Interests, and American Trade Policy. Ithaca, New York: Cornell University Press.

Grossman, Gene M. and Elhanan Helpman. 1994. "Protection for Sale." The American Economic Review Volume 84 Number 4.

Guisinger, Alexandra. 2009. "Determining Trade Policy: Do Voters Hold Politicians Accountable?" International Organization Volume 63.

Hainmueller, Jens, and Michael Hiscox. 2006. "Learning To Love Globalisation: Education and Individual Attitudes toward International Trade.” International Organization Volume 60.

Herbener, Jeffery. 1987. "The Integration of The Wealth of Nations The Theory of Moral Sentiments." The Journal of Libertarian Studies Volume VIII Number 2.

Hiscox, Michael. 2001. "Class Versus Industry Cleavages: Inter-Industry Factor Mobility and the Politics of Trade.” International Organization Volume 55 Number 1.

Hiscox, Michael. 2006. “Through A Glass Darkly: Framing Effects and Individuals' Attitudes toward Trade.” International Organization Volume 60. 
Hopenhayn, Hugo A. 1992. "Entry, Exit, and firm Dynamics in Long Run Equilibrium." Econometrica Volume 60 Number 5.

Horowitz, Gad. 1966. "Conservatism, Liberalism and Socialism in Canada: An Interpretation." Canadian Journal of Economics and Political Science Volume 32 Number 2.

International Labour Organization and World Trade Organization. 2007. Trade and Employment Challenges for Policy Research. Geneva: ILO and WTO.

Keynes, John M. 1936. The General Theory of Employment Interest and Money. New York: Harcourt, Brace.

Kinder, Donald R. and D. Roderick Kiewiet. 1979. "Economic Discontent and Political Behavior: The Role of Personal Grievances and Collective Economic Judgements in Congressional Voting." American Journal of Political Science Volume 23.

Kindleberger, Charles. 1973. The World in Depression 1929-1939. University of California Press.

Krasner, Stephen D. 1976. "State Power and the Structure of International Trade." World Politics Volume 28 Number 3.

Krugman, Paul. 1980. "Scale Economies, Product Differentiation, and the Pattern of Trade." The American Economic Review Volume 70 Number 5.

Krugman, Paul. 2008. "Trade and Wages, Reconsidered.” Brookings Papers on Economic Activity.

Lawrence, Robert Z. 2008. Blue-Collar Blues: Is Trade to Blame for Rising US Income Inequality? Washington, D.C.: Institute for International Economics.

Lindblom, Charles E. 1949. Unions and Capitalism. New Haven: Yale University Press.

Lipset, Seymour M. 1996. American Exceptionalism: A Double-Edged Sword. New York: W.W. Norton \& Company.

Lowi, Theodore J. 1963. "American Business, Public Policy, Case-Studies, and Political Theory." World Politics Volume 16.

Magee, Stephen P., William A. Brock, and Leslie Young. 1989. Black Hole Tariffs and Endogenous Policy Theory. New York: Cambridge University Press.

Mansfield, Edward D., and Diana C. Mutz. 2009. "Support for Free Trade: Self-Interest, Sociotropic Politics, and Out-Group Anxiety.” International Organization Volume 63.

Marx, Karl. 1848. "Speech on the Question of Free Trade Delivered to the Democratic Association of Brussels at its Public Meeting of January 9, 1848.” In Sitton (2010).

Matschke, Xenia. 2004. Labour Market Rigidities and the Political Economy of Trade Protection. SCCIE Working Paper \#04-2. Santa Cruz, California: Santa Cruz Center for International Economics.

Matusz, Steven J. 1994. "International Trade Policy in a Model of Unemployment and Wage Differentials." The Canadian Journal of Economics Volume 27 Number 4.

McCulloch, Rachel. 2006. "Protection and Real Wages: The Stolper-Samuelson Theorem." Processed. Chapter in Szenberg et al. (2006).

Melitz, Marc. 2003. "The Impact of Trade on Intra-Industry Reallocations and Aggregate Industry Productivity." Econometrica Volume 71 Number 6.

Milner, Helen V., Raymond Hicks, and Dustin H. Tingley. 2010. "Trade Policy, Economic Interests and Party Politics in a Developing Country: The Political Economy of CAFTA." Processed.

Milner, Helen V. and Dustin H. Tingley. 2010. "Who Supports Global Economic Engagement? The Sources of Preferences in American Foreign Economic Policy.” Processed. 
Mutz, Diana C., and Jeffery J. Mondak. 1997. "Dimensions of Sociotropic Behavior: Group-Based Judgments of Fairness and Well-Being." American Journal of Political Science Volume 41 Number 1 .

Okun, Arthur M. 1975. Equality and Efficiency: The Big Trade-Off. Wahington, D.C.: The Brookings Institution.

Olson, Mancur. 1982. The Rise and Decline of Nations: Economic Growth, Stagflation, and Social Rigidities. New Haven: Yale University Press.

O'Rourke, Kevin H. and Richard Sinnott. 2002. "The Determinants of Individual Trade Policy Preference: International Survey Evidence.” In Collins and Rodrik (2002).

Palokangas, Tapio. 2000. Labour Unions, Public Policy and Economic Growth. Cambridge: Cambridge University Press.

Pastor, Robert A. 1980. Congress and the Politics of US Foreign Economic Policy, 1929-1976. Berkeley, California: University of California Press.

Pincus, Jonathan J. 1977. Pressure Groups and Politics in Antebellum Tariffs. New York: Columbia University Press.

Pontusson, Jonas. 1993. "The Comparative Politics of Labour-Initiated Reforms: Swedish Cases of Success and Failure.” Comparative Political Studies Volume 25 Number 4.

Pontusson, Jonas. 2005. Inequality and Prosperity: Social Europe Vs. Liberal America. Ithaca, N.Y.: Cornell University Press.

Ricardo, David. 1821. On the Principles of Political Economy and Taxation.

Rogowski, Ronald. 1989. Commerce and Coalitions: How Trade Affects Domestic Political Alignments. Princeton: Princeton University Press.

Schattschneider, Elmer E. 1935. Politics, Pressure, and the Tariff: A Study of Free Private Enterprise in Pressure Politics, as Shown in the 1929-1930 Revision of the Tariff. New York: Prentice Hall.

Schattschneider, Elmer E. 1960. The Semi-Sovereign People: A Realist's View of Democracy in America. New York: Holt, Rinehart and Winston.

Scheve, Kenneth F. and Matthew J. Slaughter. 2001a. Globalisation and the Perceptions of American Workers. Washington, D.C.: Institute for International Economics.

Scheve, Kenneth F. and Matthew J. Slaughter. 2001b. "What Determines Individual Trade-Policy Preferences?” Journal of International Economics Volume 54.

Schonhardt-Bailey, Cheryl. 1991. "Lobbying for Free Trade in 19 ${ }^{\text {th }}$-Century Britain: To Concentrate or Not." American Political Science Review Volume 85 Number 1.

Sitton, John F., ed. 2010. Marx Today: Selected Works and Recent Debates. New York: Palgrave Macmillan.

Smith, Adam. 1776. Edited by R.H. Campbell and A.S. Skinner, eds. 1981. An Inquiry into the Nature and Causes of the Wealth of Nations. Glasgow edition of the works and correspondence of Adam Smith. Indianapolis: Liberty Classics.

Smith, Adam. 1790. The Theory of Moral Sentiments. Sixth edition. Edited by Sálvio M. Soares. MetaLibri.

Stiglitz, Joseph E. and Andrew Charlton. 2005. Fair Trade for All: How Trade Can Promote Development. Oxford: Oxford University Press.

Stolper, Wolfgang and Paul Samuelson. 1941. "Protection and Real Wages." Review of Economic Studies Volume 9. 
Szenberg, Michael, Aron Gottesman, and Lall Ramrattan, eds. Samuelsonian Economics and the $21^{\text {st }}$ Century. Oxford: Oxford University Press.

de Tocqueville, Alexis. 1835. Democracy in America.

VanGrasstek, Craig. 1997. "The Political Economy of Trade Policy in the United States Senate: Parochialism and Pluralist Barter.” Doctoral dissertation (Princeton University).

Verba, Sidney, Steven Kelman, Gary R. Orren, Ichiro Miyake, Joji Watanuki, Ikuo Kabashima, and G. Donald Ferree, Jr. 1987. Elites and the Idea of Equality: A Comparison of Japan, Sweden, and the United States. Cambridge: Harvard University Press.

Viner, Jacob. 1927. “Adam Smith and Laissez Faire.” The Journal of Political Economy Volume 35 Number 2.

Wallerstein, Michael. 1987. "Unemployment, Collective-Bargaining, and the Demand for Protection.” American Journal of Political Science Volume 31 Number 4.

Weller, Jürgen. 2009a. "The Improvement of Labour-Market Institutions in Latin America: Progress and Challenges." Chapter in Weller (2009b).

Weller, Jürgen, editor. 2009b. Regulation, Worker Protection and Active Labour-Market Policies in Latin America. Santiago, Chile: ECLAC.

Williamson, Jeffrey G. 2003. Was It Stolper-Samuelson, Infant Industry or Something Else? World Trade Tariffs 1789-1938. NBER Working Paper No. 9656.

Yotov, Yoto V. 2010. “Trade-Induced Unemployment: How Much Do We Care?” Review of International Economics Volume 18 Number 5. 


www.oecd.org/trade

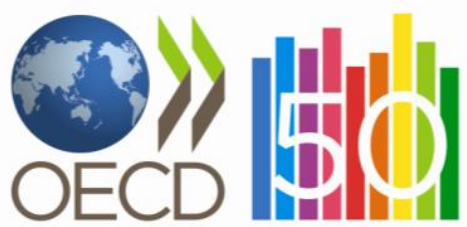

